\title{
PENGARUH FISCAL STRESS TERHADAP TINGKAT KEJAHATAN DAN PENDAPATAN PERKAPITA PADA PEMERINTAH KABUPATEN/KOTA DI INDONESIA
}

\author{
SKRIPSI \\ Diajukan Untuk Memenuhi Salah Satu Syarat Memperoleh Gelar Sarjana \\ Program Studi Akuntansi
}

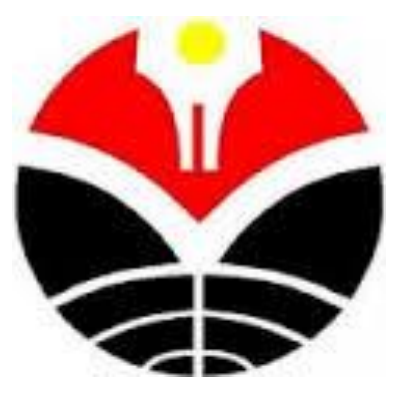

Disusun Oleh :

Mitha Krismayanti

1401287

PROGRAM STUDI AKUNTANSI

FAKULTAS PENDIDIKAN EKONOMI DAN BISNIS

UNIVERSITAS PENDIDIKAN INDONESIA

BANDUNG

2019 


\title{
PENGARUH FISCAL STRESS TERHADAP TINGKAT KEJAHATAN \\ DAN PENDAPATAN PERKAPITA PADA PEMERINTAH KABUPATEN/KOTA DI INDONESIA
}

\author{
Oleh: \\ Mitha Krismayanti \\ NIM. 1401287
}

Sebuah skripsi yang diajukan untuk memenuhi salah satu syarat memperoleh gelar Sarjana Ekonomi pada Fakultas Pendidikan Ekonomi dan Bisnis

\author{
(C) Mitha Krismayanti
}

Universitas Pendidikan Indonesia

April 2019

Hak Cipta dilindungi undang-undang

Skripsi ini tidak boleh diperbanyak seluruhnya atau sebagian, dengan dicetak ulang, difoto copy, atau cara lainnya tanpa izin dari penulis. 
LEMBAR PENGESAHAN

\section{PENGARUH FISCAL STRESS TERHADAP TINGKAT KEJAHATAN \\ DAN PENDAPATAN PERKAPITA PADA PEMERINTAH \\ KABUPATEN/KOTA DI INDONESIA}

SKRIPSI

Disusun Oleh :

Mitha Krismayanti

1401287

Telah disetujui oleh :

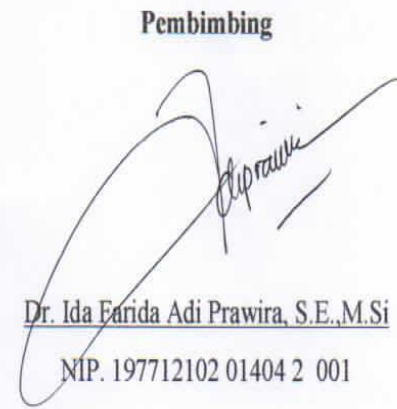

Mengetahui,

Ketua Program Studi Akuntansi

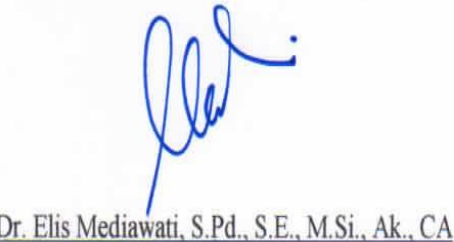

NIP. 198201232005012002 


\section{PERNYATAAN KEASLIAN NASKAH}

Dengan ini saya menyatakan bahwa skripsi dengan judul "Pengaruh Fiscal Stress terhadap Tingkat Kejahatan dan Pendapatan Perkapita pada Pemerintah Kabupaten/Kota di Indonesia” beserta seluruh isinya adalah benarbenar karya sendiri dan saya tidak melakukan penjiplakan atau pengutipan dengan cara-cara yang tidak sesuai dengan etika keilmuan yang berlaku dalam masyarakat keilmuan. Atas pernyataan ini, saya siap menanggung risiko/sanksi yang dijatuhkan kepada saya apabila kemudian ditemukan adanya pelanggaran terhadap etika keilmuan dalam karya saya ini, atau ada klaim dari pihak lain terhadap keaslian naskah ini.

Bandung, April 2019

Yang membuat pernyataan,

Mitha Krismayanti 


\title{
ABSTRAK \\ PENGARUH FISCAL STRESS TERHADAP TINGKAT KEJAHATAN DAN PENDAPATAN PERKAPITA PADA PEMERINTAH KABUPATEN/KOTA DI INDONESIA
}

\author{
Oleh: \\ Mitha Krismayanti \\ 1401287
}

Dosen Pembimbing:

Dr. Hj. Ida Farida Adi Prawira, SE, M.Si

Penelitian ini bertujuan untuk mengetahui : 1) Pengaruh fiscal stress terhadap tingkat kejahatan pada pemerintah kabupaten/kota di Indonesia tahun 2014-2015, 2) Pengaruh fiscal stress terhadap pendapatan perkapita pada pemerintah kabupaten/kota di Indonesia tahun 2014-2015. Unit analisis adalah Pemerintah Kabupaten dan Kota di Indonesia. Populasi penelitian ini adalah 508 Pemerintah Kabupaten dan Kota di Indonesia, pemilihan sampel ditentukan berdasarkan kriteria purposive sampling sehingga didapatkan 53 pemerintah kabupaten/kota yang menjadi sampel dalam penelitian ini. Data yang digunakan adalah data sekunder yang diperoleh dari website Direktorat Jenderal Pajak Keuangan (DJPK) berupa Laporan Realisasi Keuangan (LRA) dan website Badan Pusat Statistik (BPS). Alat uji hipotesis dalam penelitian ini menggunakan software Eviews 9. Dari hasil pengujian didapatkan bahwa 1) Fiscal stress berpengaruh terhadap tingkat kejahatan secara negatif. dan 2) Fiscal stress berpengaruh terhadap pendapatan perkapita secara negatif.

Kata Kunci: Fiscal Stress, Tingkat Kejahatan,Pendapatan Perkapita. 

.Error! Bookmark not defined. ABSTRAK ..Error! Bookmark not defined. ABSTRACT ...Error! Bookmark not defined. KATA PENGANTAR ...Error! Bookmark not defined. UCAPAN TERIMA KASIH. Error! Bookmark not defined.

DAFTAR ISI .67

DAFTAR TABEL .69

DAFTAR GAMBAR . .70

DAFTAR GRAFIK. .71

DAFTAR LAMPIRAN .72

BAB I PENDAHULUAN Error! Bookmark not defined.

1.1 Latar Belakang Error! Bookmark not defined.

1.2 Rumusan Masalah Error! Bookmark not defined.

1.3 Tujuan Penelitian ...Error! Bookmark not defined.

1.4 Manfaat Penelitian Error! Bookmark not defined.

1.4.1 Manfaat Teoritis Error! Bookmark not defined.

1.4.2 Manfaat Praktis Error! Bookmark not defined. BAB II KAJIAN PUSTAKA Error! Bookmark not defined.

2.1 Landasan Teoritis ...Error! Bookmark not defined.

2.1.1 Fiscal Stress Error! Bookmark not defined.

2.1.2 Definisi Kejahatan. ...Error! Bookmark not defined.

2.1.3 Pendapatan Per Kapita Error! Bookmark not defined.

2.1.4 Pengaruh Fiscal Stress Terhadap Tingkat Kejahatan .... Error! Bookmark not defined.

2.1.5 Pengaruh Fiscal Stress Terhadap Pendapatan Per Kapita ....... Error! Bookmark not defined.

2.2 Penelitian Terdahulu Error! Bookmark not defined.

2.3 Kerangka Pemikiran Error! Bookmark not defined. 
2.4 HipotesisPenelitian ...Error! Bookmark not defined.

BAB III METODE PENELITIAN ..Error! Bookmark not defined.

3.1 Objek Penelitian Error! Bookmark not defined.

3.2 Metode Penelitian Error! Bookmark not defined.

3.2.1 Desain Penelitian Error! Bookmark not defined.

3.2.2 Definisi dan OperasionalisasiVariabel Error! Bookmark not defined.

3.3 Populasi dan Sampel Penelitian ...............Error! Bookmark not defined.

3.3.1 Populasi Penelitian ...........................Error! Bookmark not defined.

3.3.2 Sampel Penelitian.............................Error! Bookmark not defined.

3.4 Teknik Pengumpulan Data .......................Error! Bookmark not defined.

3.5 Teknik Analisis Data ...............................Error! Bookmark not defined.

3.5.1 Statistik Deskriptif ...........................Error! Bookmark not defined.

3.5.2 Teknik Analisis Data Regresi Data Panel ...... Error! Bookmark not defined.

3.5.3 Regresi Data Panel ...........................Error! Bookmark not defined.

3.6 Pengujian Hipotesis .................................Error! Bookmark not defined.

BAB IV HASIL PENELITIAN DAN PEMBAHASAN ..... Error! Bookmark not defined.

4.1 Hasil Penelitian.........................................Error! Bookmark not defined.

4.1.1 Tinjauan Umum Subyek Penelitian .Error! Bookmark not defined.

4.1.2 Analisis Deskriptif Variabel Penelitian.......... Error! Bookmark not defined.

4.1.3 Analisis Data ...................................Error! Bookmark not defined.

4.2 Pembahasan .............................................Error! Bookmark not defined.

4.2.1 Pengaruh Fiscal Stress Terhadap Tingkat Kejahatan .............. Error!

Bookmark not defined.

4.2.2 Pengaruh Fiscal Stress terhadap Pendapatan Perkapita........... Error! Bookmark not defined.

BAB V SIMPULAN, IMPLIKASI DAN REKOMENDASI ..... Error! Bookmark not defined.

5.1 Simpulan .................................................Error! Bookmark not defined.

5.2 Implikasi dan Rekomendasi .....................Error! Bookmark not defined.

DAFTAR PUSTAKA .............................................Error! Bookmark not defined. 
LAMPIRAN

...Error! Bookmark not defined. 


\section{DAFTAR TABEL}

Tabel 1.1 Tren APBD Kabupaten dan Kota di Indonesia Tahun 2010-2017 Error! Bookmark not defined.

Tabel 1.2 Data Fiscal Stress, Tingkat Kejahatan dan Pendapatan PerKapita Kabupaten/Kota di Indonesia .................Error! Bookmark not defined.

Tabel 2.1 Penelitian Terdahulu ..............................Error! Bookmark not defined.

Tabel 3.1 Operasionalisasi Variabel .......................Error! Bookmark not defined.

Tabel 3.2 Daftar Sampel Penelitian .......................Error! Bookmark not defined.

Tabel 4.1 Daftar Sampel Penelitian .......................Error! Bookmark not defined.

Tabel 4.2 Statistik Deskriptif Fiscal Stress Periode 2014 dan 2015 .............. Error!

Bookmark not defined.

Tabel 4.3 Statistik Deskriptif Tingkat Kejahatan Periode 2014 dan 2015..... Error! Bookmark not defined.

Tabel 4.4 Statistik Deskriptif Pendapatan Perkapita Periode 2014 dan 2015 Error! Bookmark not defined.

Tabel 4.5 Hasil Pengujian Uji Chow Hipotesis 1 ...Error! Bookmark not defined. Tabel 4.6 Hasil Pengujian Uji Chow Hipotesis 2 ...Error! Bookmark not defined. Tabel 4.7 Hasil Pengujian Fixed Effect Model Hipotesis 1. Error! Bookmark not defined.

Tabel 4.8 Hasil Pengujian Fixed Effect Model Hipotesis 2. Error! Bookmark not defined. 
DAFTAR GAMBAR

Gambar 2.1 Kerangka Pemikiran ...........................Error! Bookmark not defined. 


\section{DAFTAR GRAFIK}

Grafik 1.1 Data Tingkat Kejahatan di Indonesia Tahun 2014-2017 .............. Error! Bookmark not defined. 


\title{
DAFTAR LAMPIRAN
}

\author{
Lampiran 1 : Tabulasi Data Fiscal Stress \\ Lampiran 2 : Tabulasi Data Hasil Perhitungan Fiscal Stress \\ Lampiran 3 : Tabulasi Data Tingkat Kejahatan \\ Lampiran 4 : Tabulasi Data Hasil Perhitungan Tingkat Kejahatan \\ Lampiran 5 : Tabulasi Data Pendapatan Perkapita \\ Lampiran 6 : Tabulasi Data Hasil Perhitungan Pendapatan Perkapita \\ Lampiran 7 : Hasil Olah Data Eviews 9 \\ Lampiran 8 : Frekuensi Bimbingan \\ Lampiran 9 : Matriks Perbaikan SUP \\ Lampiran 10 : Lembar Persetujuan Revisi SUP \\ Lampiran 11 : Lembar Persetujuan Revisi Ujian Sidang \\ Lampiran 12 : Sertifikat TOEFL \\ Lampiran 13 : Daftar Riwayat Hidup
}




\section{DAFTAR PUSTAKA}

Ajija, R. S., Sari, W. D., Setianto, R., \& Primanti, M. (2011). Cara Cerdas Menguasai EViews. Jakarta: Salemba Empat.

Arnett, S. (2011). Fiscal Stress in the U . S . States : an Analysis of Measures and Responses. $\quad$ Retrieved from https://smartech.gatech.edu/xmlui/bitstream/handle/1853/42860/arnett_sarah _b_201112_phd.pdf?sequence=1

Badan Pusat Statistik. (2016). Statistik Kriminal. Retrieved from www.bps.go.id

Badan Pusat Statistik. (2018). Statistik Kriminal 2018. Retrieved January 31, 2018, from https://www.bps.go.id

Dengah, S., Rumate, V., \& Niode, A. (2014). Analisis Pengaruh Pendapatan Perkapita dan Jumlah Penduduk Terhadap Permintaan perumahan Kota Manado Tahun 2003-2012, 14(3), 71-81.

DiNapoli, T. P. (2018). Municipalities Designated in "Significant Fiscal Stress" Doubles. Retrieved October 28, 2018, from https://www.osc.state.ny.us/press/releases/sept18/092518.htm

Direktorat Jenderal Perimbangan Keuangan. (2018). Data Keuangan Daerah. Retrieved October 15, 2018, from http://www.djpk.kemenkeu.go.id/?p=5412

Elling, R., Krawczyk, K., \& Carr, J. (2013). What Should We Do? Public Attitudes about How Local Government Officials Should Confront Fiscal Stress. Local Government Studies, 40(3), 380-402. https://doi.org/10.1080/03003930.2013.823408

Finegold, K., Schardin, S., \& Steinbach, R. (2003). How Are States Responding to Fiscal Stress? New Federalism:Issues and Options for States, 1-7.

Forrester, J. P., \& Spindler, C. J. (1990). Managing Municipal Services In An Of Declining Federal Assistance, 10(1), 63-84.

Ghozali, I., \& Ratmono, D. (2013). Analisis Multivariant dan Ekonometrika (Teori, konsep, dan Aplikasi) Eviews 8. Semarang: Universitas Diponegoro Semarang.

Gujarati, \& Porter. (2009). Dasar-Dasar Ekonometrika. Jakarta: Salemba Empat.

Halim, A. (2001). Anggaran Daerah dan Fiscal Stress. Ekonomi Dan Bisnis 
Indonesia, 16(4), 346-357.

Junita, A., \& Abdullah, S. (2016). Pengaruh Fiscal Stress Dan Legislature Size Terhadap Expenditure Change Pada Kabupaten/Kota Di Sumatera Utara. Jurnal Akuntansi, 20(3). https://doi.org/10.24912/ja.v20i3.10

Kaltara, R. (2016). Defisit Anggaran Tak Pengaruhi Pertumbuhan Ekonomi. Retrieved January 7, 2019, from m.kaltara.prokal.co

Kaltara, R. (2017). Angka Kriminalitas Naik 62,41 Persen. Retrieved January 31, 2019, from http://kaltara.prokal.co/read/news/8785-angka-kriminalitas-naik6241-persen.html

Kuncoro, M. (2004). Otonomi dan Pembangunan Daerah. Jakarta: Erlangga.

Maher, C. S., \& Deller, S. C. (2007). Municipal responses to fiscal stress. International Journal of Public Administration, 30(12-14), 1549-1572. https://doi.org/10.1080/01900690701230184

Maulana, T. (2014). Pengaruh Umum, Pendidikan, Pendapatan dan Jumlah Tanggungan Keluarga Terhadap Tingkat Kejahatan Pencurian dengan Pendekatan Ekonomi.

Merriam, R. E., \& Chairman. (1973). City Financial Emergencies: The Intergovernmental Dimension.

Muda, I. (2015). Variabel yang Mempengaruhi Fiscal Stress pada Kabupaten/Kota Sumatera Utara, 4(1), 27-46. https://doi.org/10.13140/2.1.3934.2880

Muryawan, S. M., \& Sukarsa, M. (2016). Pengaruh Desentralisasi Fiskal, Fiscal Stress, dan Kinerja Keuangan Daerah terhadap Pertumbuhan Ekonomi di Kabupaten/Kota Provinsi Bali. E-Jurnal Ekonomi Dan Bisnis, 5(2), 229-252. Retrieved from http://ojs.unud.ac.id/index.php/EEB/article/view/9379

Pagano, M. (1993). balancing cities' Books in 1992: An Assessment of City Fiscal Conditions.

Reschovsky, A. (2003). The Implication of State Fiscal Stress for Local Governments. Urban Institute Conference, State Fiscal Crises: Causes, Consequences, \&Solutions. Retrieved from http://taxpolicycenter.org/UploadedPDF/1000612.pdf

Rohmana, Y. (2010). Ekonometrika Teori dan Aplikasi Eviews. Bandung: Laboratorium Pendidikan Ekonomi dan Koprasi, FPEB, UPI Bandung.

Rosadi, D. (2012). Ekonometrika \& Analisis Runtun Waktu Terapan Dengan EViews. Yogyakarta: Andi Publisher.

Sekaran, U. (2006). Research Methods For Business. Jakarta: Salemba Empat.

Sekaran, U. (2009). Research Methods For Business. Jakarta: Salemba Empat.

Shamsub, H., \& Akoto, J. B. (2004). State and Local Fiscal Structures and Fiscal 
Stress. Journal of Public Budgeting, Accounting \& Financial Management, 16(1), 40-61.

Skidmore, M., \& Scorsone, E. (2011). Causes and consequences of fiscal stress in Michigan cities. Regional Science and Urban Economics, 41(4), 360-371. https://doi.org/10.1016/j.regsciurbeco.2011.02.007

Subana, M., \& Sudrajat. (2005). Dasar-Dasar Penelitian Ilmiah. Bandung: Pustaka Setia.

Sugiyarto. (2018). PDRB Nunukan Masih Didominasi Pertambangan dan Galian. Retrieved January 31, 2019, from http://www.tribunnews.com/regional/2018/03/26/pdrb-nunukan-masihdidominasi-pertambangan-dan-galian.

Thompson, P. N. (2017). Effects of fiscal stress labels on municipal government finances, housing prices, and the quality of public services: Evidence from Ohio. Regional Science and Urban Economics, 64(March), 98-116. https://doi.org/10.1016/j.regsciurbeco.2017.03.001

Todaro, M. P. (2006). Pembangunan Ekonomi di Dunia Ketiga. Jakarta: Erlangga.

Wibowo, D. (2015). Pengaruh pendapatan per kapita, economic growth rate, economic structure, dan tax rate terhadap tax ratio pada negara-negara oecd dan indonesia, 45-61. 